\title{
Sági Mária
}

\section{AZ INFORMÁCIÓ SZEREPE A KÜLÖNBÖZŐ PARADIGMÁKBAN}

\section{DOI 10.35402/kek.2021.2.17}

Korunk kulcsfogalma az információ. A magyar nyelvben az értesítés, felvilágosítás, tájékoztatás, tudósítás, értesülés, hír fogalmakkal helyettesíthetnénk, a latin és az angol ennél többet mond: a latin informo igei alakja 'formál, alakít', az angol értelmező szótár pedig így magyarázza az általunk kevésbé ismert igei alakot: minőséggel, esszenciával áthat, eltölt.

A hírről, tudósításról tudjuk, hogy szellemi és nem anyagi természetű, mégis egy hír megváltoztathatja, átformálhatja gondolatainkat, cselekedeteinket. Gondoljunk arra, ha természeti katasztrófákról, balesetekről értesülünk, mennyire megrendít bennünket. Az ember vagy szélesebb értelemben az élővilág számára az információ ebből a szempontból jelentős: az üzenet formálja a vevőt. Egy computer felveszi az információt, tárolja és továbbadja, de mint egész rendszer nem változik meg tőle. Az állat és az ember igen.

\section{Mi a paradigma?}

A paradigma (vagy korszellem) azoknak a gondolkodásoknak, vélekedéseknek, értékeknek és módszereknek az összességét jelenti, amelyet egy adott társadalom vagy szükebben egy tudományos közösség minden tagja elfogad.

A paradigma és a paradigmaváltás fogalmát Thomas Kuhn (1922-1996) A tudományos forradalmak szerkezete (Structure of Scientific Revolutions) c. műve tette ismertté az 1960-as években. A mü eredetileg cikként jelent meg az Egyesített Tudomány Nemzetközi Enciklopédiájában a Bécsi Kör logikai pozitivistái jóvoltából. A mű alapötlete egy megvilágosodásszerű élményre épül, amely Arisztotelész Fizikájának tanulmányozása közben érte a szerzőt.

A könyvben Kuhn azt mutatja be, hogy a tudomány nem az új ismeretek lineáris felhalmozódásával halad előre, hanem időszakos forradalmakon megy keresztül, melyek során a tudományos érdeklődés egy-egy területen hirtelen alakul át. Kuhn - nem először a tudományos irodalomban - „paradigmaváltásoknak" nevezi ezeket az időszakokat. $\mathrm{Az}$ új paradigma kialakulása Kuhn szerint három különböző szakaszra osztható. Az első a megsejtés, melyből hiányzik a központi paradigma. Ezt követi a „szokásos” tudomány, vagyis a kutatási folyamat, amikor a tudósok „puzzlekirakással” próbálják meg szélesíteni a központi paradigmát. Ha pedig a paradigma sikeres, a 'foáramlatú' (main stream) tudomány vezérelvévé válik. Ez a harmadik szakasz.

\section{Ösi paradigmák}

Mind az ókori civilizációkban, mind a törzsi, természeti népeknél természetesnek találták, hogy az ember szerves része környezetének, összeköttetésben van a külvilággal, állandó kölcsönhatásban, kommunikációban áll minden élővel és élettelennel. Ezért nem nyomták el azt a finom rezgésszintű érzékelést, amelyet a környező világról az érzékszerveken túli (ESP) érzékelés útján kaptak. Az ún. finomenergiák érzékelése része volt a tapasztalatuknak, és ezért a tudat is foglalkozott vele. Magától értetődő volt az is, hogy a természet nemcsak fizikai anyagból áll, hogy az ember anyagi teste csak egyik dimenziója az élő szervezetnek. Ahogy az anyagi test részeit, úgy a lelki, szellemi, energetikai dimenziót is számon tartották, az erről való ismereteiket rendszerezték. Úgy lelkük, mint fizikai testük gyógyításával is foglalkoztak, sőt sok esetben a test gyógyulásához a lelki, szellemi, energetikai dimenziók gyógyításán keresztül jutottak el. Az egységes, holisztikus világszemlélet lelki, szellemi, energetikai dimenziója kultúránként más-más hitrendszerben jelenik meg. (Lásd a közel- és távol-keleti és más ókori kultúrákat). Az ősi kultúrák bölcseleti hagyományaiban megjelenik az a tudás, amely szerint a világ tökéletesen összehangolt rend szerint működik.

A világegyetem információval töltött intelligenciáját különbözőképp nevezték: mint például Brahman, Isten, Jahve, Tao, Világszellem. Az indiai Védákban rögzített szanszkrit Akasha világfelfogás szerint a shabda, az eredendő rezgés (az angol nyelvben ripple - fodrozódás), amely megalkotja a világegyetemet; teszi ezt pedig az első 'spanda'-val, a szellem megrezdülésével. A belső, vagyis mindent magába foglaló rend tulajdonképpen az Akashamező. Az ősi indiai metafizikai kozmológiában ez 
volt a fundamentális valóság, alapvetőbb, mint a föld, a levegő, a tủz és a víz.

Iqbal Kishen Taimni (1898-1978) indiai tudós szerint létezik egy titokzatosan integrált (beépített) rezgésállapot, amelyből az összes rezgésforma levezethető egy differenciálási folyamat során (Taimni 1969:276-280). A szanszkrit nyelvben ezt $N . d a-$ nak nevezik. A N.da egy bizonyos közegben lévő rezgés, amelyet az angolban 'tér'-nek fordítanak. Itt azonban nem csupán egy üres térről beszélünk, hanem egy entitásról, mely számunkra talán üresnek tűnik, ez az entitás azonban végtelen mennyiségü potenciális energiát tartalmaz. Ez nem más, mint egy végtelen potencialitás, amelyből minden fajta, mindenféle intenzitású és mennyiségü rezgés eredeztethető. Potencialitása abból származik, hogy az Akashában rejtve benne foglaltatik a szellem.

\section{Mai foáramlatú paradigma megjelenése}

A középkortól kezdődően a keresztény egyház egyre erősödő uralma alatt a hitrendszer és vele együtt az emberek életszemlélete is átalakult. A valaha egységes szemlélet kettészakadt: egy mechanikus, gépies és egy spirituális oldalra. Az erkölcsi igazságok meghatározása, 'irányítása' az egyház kezében volt, míg a természetfilozófiát vonakodva ugyan, de jóváhagyták, mint a szerzetesi falakon túl élő laikusok területét. Ezáltal a látható világ „elemi tulajdonságainak" megfigyelése szabad utat kapott a fejlődésre.

A középkori európai kultúra gyakorlati hajlamának megfelelően az Egyháztól való viszonylag függetlenül kialakult világképet a mechanikus eszközökkel szerzett tapasztalat alapján modellezték. A világ egészét egy hatalmas gépezetként fogták fel.

A XVII. század elején a távcső feltalálása, majd tökéletesítése forradalmi változásokat hozott Európában. A csillagászat mellett a fizika és a matematika ismereti határai is kitágultak. A mechanikus világkép gyors fejlődésen ment keresztül a teleszkópnak, valamint a Galilei és Kepler munkássága révén tett felfedezésnek köszönhetően, mely szerint a mennyek világa ugyanazoknak a mechanikus törvényeknek engedelmeskedik, mint amelyek a Földet is uralmuk alatt tartják.

1687-ben megjelent Sir Isaac Newton (16421727) korszakalkotó műve a Philosophiae Naturalis Principa Mathematica (A természetfilozófia matematikai alapelvei), melyben leírja az egyetemes tömegvonzás törvényét, valamint az általa lefektetett axiómák révén megalapozta a klasszikus mechanika tudományát. Ô volt az első, aki megmutatta, hogy az égitestek és a Földön lévő tárgyak mozgását ugyanazon természeti törvények határozzák meg. Matematikai magyarázattal alátámasztotta Kepler bolygómozgási törvényeit, kiegészítve azzal, hogy a különböző égitestek nemcsak elliptikus, de akár hiperbola- vagy parabolapályán is mozoghatnak. Törvényei fontos szerepet játszottak a tudományos forradalomban és a heliocentrikus világkép elterjedésében.

Newton természetfilozófia terén végzett kutatásai munkásságának csak egyik oldalát jelentik. Ő maga úgy tartotta, hogy a törvényei csupán a mélyebb valóság felszíni megnyilvánulásaira érvényesek. Az új fizika kutatásai már felhívják figyelmünket Newton spirituális tartalmú írásaira, melyeket napjainkban a Londoni Nemzeti Könyvtárban (The British Library, London) kézirat formában őriznek.

Newton követői azonban a newtoni szintézist egy mechanikus világképpé szűkítették. Ettől kezdve a fóáramlatú tudomány minden ismert ága a 'newtoni' klasszikus mechanikus elméletre épült: miszerint a világegyetem a mechanika törvényszerüségei szerint működő anyagi részecskék összessége.

$\mathrm{Az}$ uralkodó materialista szemlélet hatására az emberek érzékelése is átalakult. A materialista szemlélet szerint nem létezik az anyagon kívüli szellem. Az emberi tudat egy epifenomenon, az agy működésének terméke. Miután úgy vélték, hogy a világban nincs más, mint az anyag és annak különböző megjelenési formái, minden teóriát, amely a materialista szemléleten túlhaladt, legjobb esetben is csak "misztikusnak”, legrosszabb esetben pedig eretnekségnek tekintettek. A huszadik század folyamán lassanként mégis világossá vált, hogy a pusztán materialista szemlélet nem képes megfelelő magyarázatot találni a newtoni fizika paradoxonjaira, valamint a posztdarwinista biológia, vagy a transzperszonális pszichológia jelenségeire.

Ma már egyértelmű, hogy a Newton-i klasszikus mechanikus szemléletre épülő világfelfogás ideje lejárt. Új világfelfogás van születőben.

\section{Új paradigma}

A 20. század végén a természettudományok fejlődése új utakra tért és eljutott az úgynevezett finomenergiák vizsgálatához. Az elmúlt évtizedek fizikai kutatásai elérik azokat a finomenergetikai mezőket, amelyeket az emberek több ezer évvel 
ezelőtt csak érzékelni tudtak, kutatni és megmagyarázni egyáltalán nem, hiszen eszközük nem volt hozzá.

A legújabb kvantumtudományok - mint a kvantumfizika, kvantumbiológia, kvantumpszichológia - kutatásai azt bizonyítják, hogy a világegyetem nemcsak anyagból áll, hanem egy ún. energiaplénumból, energiaállapotból, amelyben hullám formában jelennek meg a különböző anyagok és még az élő szervezetek is ennek az energiaplénumnak a különböző hullámsűrűségei. Minden egyes anyag és minden élő létező egymással szoros összeköttetésben áll. Ez a kapcsolat annyira szoros, hogy bármilyen változás az egyik elemben a rendszer öszszes többi elemére hatást gyakorol. Az anyagi világ nagyon bonyolult, nagyon finom információ öszszeköttetésen alapuló rendszer, amely a lehető legérzékenyebben van összehangolva, és amely nélkül a Föld ökológiai egysége is elképzelhetetlen lenne.

László Ervin összegezésül a jelenség magyarázatául az ún. kvantum-vákum figyelembevételét ajánlja.

A kvantumvákuum nem üres tér. Jelentős eleme a világegyetemnek, ezért elvárható, hogy valamilyen módon az univerzum minden folyamatában részt vegyen. A kvantumvákuum egy plénum, amely rezgéssel és különböző - elektromágneses, gravitációs, nukleáris és más - erőkkel van töltve. Ez a kozmosz alapállapota. David Bohm 'implicit' és 'explicit order'-rôl, azaz külső és belső rendről beszél. Így fogalmazott: „A mai fizikában az anyag nem pusztán a részecskék egyszerü csoportosulásának a helye, hanem erötér, energia, információ, vibráció és kavargás, olyan erömezö, amelyet az ember bizonyos állapotban különös módon megérez, amellyel kontaktusba lép, és amelynek létezéséböl lényegében részesül" (Bohm 1980:xviii).

A világegyetem tehát nem apró anyagdarabokból (anyagi részecskékből) áll, amelyek a mechanikus törvényeknek engedelmeskedve mozognak, sokkal inkább egy egybefüggő egész rendszer, amelyben az egyes elem összeköttetésben áll az öszszes többi elemmel, oly módon, amely meghaladja az eddig ismert tér-idő korlátait. Az új felfogás szerint az elemek (tárgyak, dolgok), amelyek benépesítik a világegyetemet nem anyagdarabokból, hanem rezgések hálójából és klasztereiből állnak. Ezek nem véletlenszerü társulások. Rendezettségük és koherenciájuk ennél sokkal többet sejtet. David Bohm szavaival élve: a rendszer in-formálva van, vagyis megadott koherens tulajdonságokkal rendelkezik. A világegyetem minden alkotórésze, beleértve saját magunkat is, egy finomenergetikai szinten nagy pontossággal megadott rend szerint épül fel. Mindannyian „jól informált” rezgéstársulások vagyunk, ahol a társulást alkotó elemek mindegyike egymással kölcsönösen együttmüködik, együttrezeg, függetlenül attól, hogy a tér-idő mely pontján található

A kvantumfizikában történt megfigyelések és számítások bizonyítják, hogy a tér ultrapici dimenziója se nem üres, se nem sima, hanem „szemcsés”, hullámokkal és rezgésekkel van töltve. Ha a fizikusok az ultrapici dimenziót vizsgálják, semmit sem találnak, amelyet anyagnak lehetne nevezni. Anyag helyett álló és mozgó hullámokat találnak, amelyek álló vagy mozgó rezgéshullámok klasztereit alkotják. Nem létezik egy „tiszta alapanyag”. ${ }^{1}$ A világegyetem a rezgések különféle módon integrált társulásainak hálója, és az anyag csak az a mód, ahogyan a rezgések megjelennek a megfigyelő számára.

A kvantumvákuum hatásai mintegy a kvantumok alatt elterjedő mezőben jelentkeznek. A mezők különös létezők: hatásuk általában megfigyelhető, de önmagukban nem észlelhetők. Szuperfinom hálóhoz lehetne hasonlítani őket. Ha a háló szálai vékonyabbak, mintsem szabad szemmel láthatnánk, akkor magát a hálót sem vehetjük észre megfelelő eszközök nélkül. Láthatjuk azonban a csomókat, ahol néhány szál találkozik. Úgy látszik, mintha a csomók lebegnének a levegőben, noha a szálak kötik őket egymáshoz, így amikor egy csomó mozog, akkor a többi is vele mozdul. Ha tehát észrevesszük, hogy egyetlen csomó mozgása kapcsolatban áll a többi csomó mozgásával, akkor fel kell tételeznünk, hogy egy viszonylag kiterjedt háló köti össze őket.

Egy mező információt is tud tárolni és továbbítani. Egy hatás (amely lényegében egy információs egység), amely egyszer létrejött, újra és újra felbukkan, előkerül. Ezt a jelenséget a kvantumfizikában az időbeni nem-lokalitásnak nevezik. A világegyetemnek ily módon emlékezete is van. Ez az emlékezet azonban nem létezhet üres térben. László Ervin szerint - Karl Pribram neurofizikus híres elmélete alapján - a maradandó információt a szubkvantum mező hologramszerű formában tárolja és továbbítja. A hologramnak az az érdekessége, hogy minden egyes részében minden információ benne van. Minden egyes részében benne van az egész. Így a természet emlékezete egy holografikus elvű információőrző és -továbbító mezőt feltételez. Ezt a mezőt László Ervin előbb pszi-mezőnek, majd

1 ground substance 
Akasha-mezőnek nevezi. Az Akasha-mezőt a fizikusok különböző nevekkel illetik: A részecskefizika nagy egységes mezőnek, az elektrodinamika zéró pont mezőnek hívja. A kvantummechanika univerzális kvantummezőnek, Bohm „belső vagy mindent magába foglaló rend"-nek nevezi. Minden, ami keletkezik és megjelenik a világegyetemben, ennek a mezőnek az egyik rezgésklasztere. Emberi testünk, a tárgyi világ minden eleme, a legparányibb atomoktól a galaxiákig mind-mind rezgésklaszterek az Akasha-mezőben; amely a világegyetem eredendő, nem anyagi alapállapota.

Max Planck (1858-1947) egyik utolsó firenzei előadásában így fogalmazott: „Én, aki egész életemben a tudományokban hittem és az anyagot kutattam, kutatásaim eredményeképpen csak azt mondhatom: olyan, mint anyag, nem létezik. Minden anyag csak egy olyan erő hatására keletkezik és marad fenn, ami az atomi részecskéket rezgésbe hozza és összekovácsolja az atom parányi naprendszerévé". Még hozzátette: az atommagokat összetartó rezgés mögötti erő mögött "feltétlenül egy tudatos és intelligens szellem létezik" (Planck 1944). Ez az intelligencia az összes létező anyag mátrixa, kapcsolódási mintája.

Két évvel Planck kinyilatkoztatása előtt Nikola Tesla így vélekedett: ha meg akarjuk ismerni a világegyetem titkát, akkor energiában, frekvenciában és rezgésekben kell gondolkodnunk. ${ }^{2}$

\section{Az információ szerepe}

Ahogy a több ezer éves kultúrák, az új világszemlélet is azt vallja, hogy a világ működése az információn alapul. Mi az az információ, amelyről itt beszélünk? Az információ egy olyan dolog, amely hat a rezgésekre és a rezgéseket egy bizonyos rendbe szervezi. Ezek a rezgések nem véletlenek, hanem egy tökéletes rend szerint léteznek és viszonyulnak egymáshoz. A világegyetem minden elemét áthatja (informálja) a kozmikus intelligencia. Bennünket, embereket - akik szintén részei vagyunk ennek a világnak - ugyanúgy áthat, informál ez az intelligencia. Ha ez a tökéletes szervezőerő nem létezne, a világban káosz lenne.

Hogyan hat a világra az információ? Miután mindenhol mindenre hat, feltételezzük, hogy úgy hat, mint egy hologram. A világegyetem egy része a kozmosznak, és a kozmikus hologram - a kozmosz holografikus intelligenciája - hat a világegyetemre:

2 If you want to find the secrets of the Universe, think in terms of energy, frequency, and vibration. „in-formálja a világegyetemet, vagyis mindent, ami időben és térben létrejön.

\section{A tudat}

Van valami a világban, amelyet úgy hívunk, tudat. A kérdés az, vajon a tudat csak az emberi agy megjelenési formája, vagy pedig van egy objektív tudat, amely létezik a világban?

A materialista felfogás szerint: az agyunk, mint anyagi szerv a működése során létrehoz egy jelenséget, amely számunkra képek, hangok, egyéb érzékelés formájában jelenik meg számunkra, vagyis valami, amelyet az érzékszerveinken keresztül felfogunk.

$\mathrm{Az}$ új szemlélet szerint a tudatot nem az agy termeli, a tudatot az agy közvetíti. Ez a felfogás már megjelent a XIX. század végén. William James (1842-1910) amerikai pszichológus, filozófus ismert pragmatista volt. Azonban olyan mértékben megrendítette az elmén túli tudat jelensége, hogy 1899-ben, Ingersoll-i előadásában azt javasolta, helyettesítsük „az agy termeli a tudatot elmélet”-et az új elmélettel, mely szerint az agy közvetíti azt.

Filozófusok, tudósok, intuitív gondolkodók mindig is kételkedtek abban, hogy a világ csak az lenne, amit az érzékszerveinken keresztül felfogni képesek vagyunk. James Jeans asztrofizikus 1930ban $A$ titokzatos világegyetem címủ könyvében ezt írta: a világ inkább hasonlít egy nagy gondolathoz, mintsem egy nagy gépezethez. ${ }^{3}$ És idézzük ismét Einsteint, aki 1936-ban egy fiatal gyereknek szóló levelében ezt írta: „Akárki, aki komolyan foglalkozik a tudománnyal, nem tudja elkerülni azt a gondolatot, hogy a világ törvényei mögött egy nagy szellem van, amelyhez képest a mi szellemünk eltörpül”.

A tudat objektív jelenléte a világban nem más, mint az információnak a jelenléte. Ez nem az az információ, amelyet köznapi értelemben használunk. Ez a természet információja, amely formálja a megjelenő világot. Ebben a csodás kvantumvilágban van egy olyan információs alap, amely úgy formálja ezeket a rezgésmintákat, hogy ebből egy koherens világ születik. A természet törvényei „utasítások”, algoritmusok, amelyek a létet határozzák meg.

Ez a szemlélet számos jelenséget magyaráz, amelyet a materialista szemlélet nem képes magyarázni. Például azt is, hogy a tudat létezik mủködő agy nélkül is. Ennek hatalmas irodalma van, ide

3 „the universe begins to look more like a great thought than like a great machine." 
tartoznak a halál-közeli élmények, a testen kívüli élmények és a legkülönbözőbb túlvilágról érkező közvetítések már régen eltávozott személyek részéről. Ugyanezen elmélet magyarázza a távgyógyítás folyamatát és mindenfajta energetikai gyógyítást, a kristályok útján való gyógyítást, hogy csak néhány példát említsünk.

Nagy jelentőséggel bír, hogy mára eljutottunk oda, hogy a kozmikus tudat alapvető eleme a világegyetemnek, és ez egyre inkább elismerést nyer. 2015-ben az arizonai Tucson városban aláirt kiáltvány ${ }^{4}$ a következőket mondja ki: A tudat a valóság egy aspektusa, ugyanolyan alapvető, mint a fizikai világ. és mint ilyet, nem lehet levezetni az anyagból, és nem lehet az egyéni agy és test müködésére korlátozni. nem bontható tovább.

A tudat a kozmosz alapeleme. Mi emberek pedig egy különösen kifinomult módon megalkotott rezgéshalmaz elemei vagyunk, testünk egy széles frekvenciasávú vevőkészülékként veszi mindazt a rezgést, amely körülvesz bennünket. Bizonyos klasztereket az agyunk fizikai tárgyakként jelenít meg (dekódol), másokat pedig a transzcendentális tudat jelenségeként élünk meg. Mivel tudatunk része a kozmikus intelligencia hologramjának, ezért érzékeli ezt a hologramot és megjeleníti a tudatunk és testünk számára a tér-idő dimenzióban.

\section{Mi az evolúció iránya?}

Természetesen nem lineáris. Vannak emelkedések és visszaesések az evolúciós folyamatokban. De ha ez a folyamat a nagy átlagot tekintve egy irányba halad, akkor koherensebbé válik, mint addig volt. Koherencia esetén a rezgésminták úgy vannak öszszekapcsolva, hogy ha az egyik alkotórészét megmozgatjuk, azonnal mozdul, változik a másik is. Ezt ismertük meg az EPR-kísérletnél ${ }^{5}$ is: ha az egyik kvantumot megmozgatjuk, a másik is úgy viselkedik, mintha a dolog vele történt volna. A világot az információ összekapcsolja.

Kétféle folyamat bontakozik ki a világban: az egyik a kvantumrészecskékből koherens rendszerekké alakuló fizikai elemek kialakulása, a másik a

4 Manifesto of the Summit on Post-Materialist Science, Spirituality and Society, Tucson. Arozina 2015.

5 EPR-paradoxon: Einstein-Podolsky-Rosen-

paradoxon) a kvantummechanika egyik nevezetes gondolat-kísérlete, amelynek eredeti célja az elmélet nem teljes voltának demonstrálása volt, később pedig a kísérleti ellenőrzésében játszott szerepet. tudat fejlödése.

Részei vagyunk a koherens rendszerek fejlődésének, megtapasztaljuk a tudat fejlődését. A rendszerekben mind a belső, mind a külső koherencia megfigyelhető, miközben egyre összetettebbé válnak a folyamatok.

Most tudatosíthatjuk magunkban, hogy a világ részei vagyunk és lehetőségünk van a 'világ természetével együttmüködve élni. Ez a legmagasabb cél, amit életünkben követhetünk.

Ez László Ervin új paradigma-üzenete.

\section{Felhasznált irodalom}

Bohm, David 1980 Wholeness and the Implicate Order, London, Routledge and Kegan Paul, p. xviii.

James, William 1970 The Conception of Immortality. (The Ingersoll lecture, 1899). Scholarly Press.

Jeans, James 1937 The Mysterious Universe. Reprint. Pelikan Books, 137.

Kuhn, Thomas 2000 A tudományos forradalmak szerkezete. Osiris Kiadó, Budapest.

Planck, Max 1944 Das Wesen der Materie. (előadás) Firenze, Olaszország. Archiv zur Geschichte der May-Planck-gesellschaft, Abt. Va. Rep. 11 Planck, Nr.1797.

Taimni, I. K. 1969. Man, God, and the Universe. The Theosophical Publishing House. Adyar, 276-280.

Sági Mária a Budapest Klub tudományos igazgatója 